\title{
Predation on livestock by large carnivores in the tropical lowlands of Guatemala
}

\author{
José R. Soto-Shoender and William M. Giuliano
}

\begin{abstract}
Conflict with humans is a significant source of mortality in carnivore populations yet information on this issue is lacking for some areas where threatened carnivores such as the jaguar Panthera onca interact with humans. We interviewed cattle ranchers to examine patterns of predation on livestock by carnivores in the tropical lowlands of Guatemala and to determine if the ranchers applied management practices recommended to prevent such predation by large felids. Additionally, we compared ranches with and without attacks on livestock to determine whether ranch characteristics and landscape structure near ranches explains the variations in the occurrence of livestock predation by carnivores. Cattle losses to carnivores represented $0.7 \%$ of the cattle stock in all ranches surveyed. Jaguars were most often accused of livestock attacks (suggesting a negative perception of this felid in the area), followed by pumas Puma concolor and coyotes Canis latrans. Males and smaller cattle were most often attacked and general patterns of attacks on livestock were similar to sites previously studied in the neotropics. Landscape structure around ranches (e.g. forest cover, distance to forest, bodies of water and human settlements) best explained the probability of predation on livestock. Outreach programmes and conflict mitigation measures need to be implemented for those ranches that are distant from human settlements but near forest cover and water sources. The co-occurrence of predation by jaguars, pumas and coyotes is particular to Mesoamerica and conflict mitigation strategies proposed in studies elsewhere may need to be altered, and evaluated, to be effective in this region.
\end{abstract}

Keywords Carnivore, coyote, Guatemala, human-carnivore conflict, jaguar, predation, puma

\section{Introduction}

T uman-wildlife conflicts have been identified as the 1 most significant cause of adult mortality in large carnivores and may lead to significant population declines, even within protected areas (Woodroffe \& Ginsberg, 1998). Consequently, efforts to identify and implement mitigation strategies for human-carnivore conflicts are required

José R. Soto-Shoender (Corresponding author) and William M. GiUliano Department of Wildlife Ecology and Conservation, University of Florida, Gainesville, Florida, 32611-0430, USA, and Wildlife Conservation Society, Program for Guatemala, Casa No. 3, Avenida 15 de Marzo, Flores, Petén, Guatemala. E-mail joesoto@ufl.edu

Received 9 July 2010. Revision requested 8 October 2010.

Accepted 16 December 2010.
(Inskip \& Zimmermann, 2009), especially at reserve borders and in buffer zones where contact between humans and carnivores is more likely (Woodroffe \& Ginsberg, 1998; Sunquist, 2002; Crawshaw, 2004). However, to propose viable and effective site-specific interventions a better understanding of spatial and temporal patterns of such conflicts is needed (Treves et al., 2006; Inskip \& Zimmermann, 2009; Rosas-Rosas et al., 2010).

In the neotropics human-carnivore conflicts typically arise when jaguars Panthera onca and pumas Puma concolor attack, or are blamed for attacks on, livestock, often resulting in the elimination of the individual carnivore believed responsible (Crawshaw, 2004). A review of studies addressing human-felid conflicts (Inskip \& Zimmermann, 2009) concluded there was a large gap in information on this issue for certain geographical areas and species. Although the predation of livestock by jaguars and pumas has been extensively studied in South America (Quigley \& Crawshaw, 1992; Hoogesteijn et al., 1993; Hoogesteijn, 2001; Mazolli et al., 2002; Conforti \& Azevedo, 2003; Polisar et al., 2003; Crawshaw, 2004; Graham et al., 2004; Zimmermann et al., 2005; Michalski et al., 2006; Azevedo \& Murray, 2007; Azevedo, 2008; Palmeira et al., 2008), few studies have examined this issue in Mesoamerica (Rabinowitz, 1986; Saenz \& Carrillo, 2002; Rosas-Rosas et al., 2008). As a result, little is known about predation on livestock in this region and it is not clear if the pattern of predation is similar to areas previously studied, or if husbandry practices and landscape features (i.e. possible mitigation factors) affect the occurrence of human-carnivore conflicts in the same manner throughout the neotropics. Conflict mitigation efforts have only recently been implemented in Mesoamerica and therefore detailed studies of this issue are required, especially in areas for which information is lacking such as the tropical lowlands of Guatemala.

The northern Petén District of Guatemala, along with adjacent protected areas in Belize and Mexico, forms part of the largest continuous forest in Mesoamerica, the Maya Forest (Grunberg, 2000). The Maya Forest has been identified as an important site for the long-term conservation of jaguars (Sanderson et al., 2002). Despite this, forest fragmentation in this district is increasing because of current land-use patterns (Grunberg, 2000; Hayes et al., 2002). Cattle ranching is one of the principal livelihoods in the area (Grunberg, 2000). Consequently, there is considerable overlap between livestock husbandry and wildlife, which may increase human-carnivore conflicts. Nevertheless, no efforts had formerly been undertaken to examine or 
mitigate this issue in the Petén District, despite its importance for the conservation of tropical carnivores.

Our objectives were to characterize patterns of predation on livestock by carnivores, determine whether ranchers implement practices to reduce predation, and test the hypothesis that the occurrence of such predation is influenced by landscape variables and ranch characteristics. We predicted that predation of livestock would be associated with landscape variables that describe prime carnivore habitat (i.e. forest cover, distance to forest and water) and with ranch size and number of cattle because we expected larger ranches with more cattle to provide better care and protection for their livestock.

\section{Study area}

The study was carried out in the $36,000 \mathrm{~km}^{2}$ Petén District of northern Guatemala (Hayes et al., 2002; Fig. 1). In the most recent census this District had a human population of 366,735 (Instituto Nacional de Estadística, 2003). Altitudes in Petén are $100-300 \mathrm{~m}$ (Grunberg, 2000), annual total precipitation is $1,300-2,500 \mathrm{~mm}$, with a wet season in June-January and dry season in February-May (McNab \& Polisar, 2002), and mean monthly temperatures are $22-34^{\circ} \mathrm{C}$ (Novack et al., 2005). The vegetation consists primarily of high canopy tropical lowland forests, seasonally-flooded lowland forests with a dense understorey of shrubs and small trees, wetlands along rivers and lakes, and savannah-like grasslands (Grunberg, 2000). Within the District there are several protected areas surrounded by human communities where the principal livelihood is cattle ranching, with c. 5,000 ranches in the District according to the most recent census (Instituto Nacional de Estadística, 2003). The main protected area in the District is the $16,000 \mathrm{~km}^{2}$ Maya Biosphere Reserve, the largest protected area in Guatemala (Hayes et al., 2002).

\section{Methods}

We used a questionnaire survey (Table 1) to interview cattle ranchers at sites within Petén District from which government and NGO personnel had received reports of predation on livestock. We first visited ranches that had reported predation and then proceeded to survey adjacent and surrounding ranches. We attempted to survey an equal number of ranches with and without attacks in each surveyed site. We did not survey ranches at random because this would have been too time consuming and may have yielded a smaller number of ranches with attacks. In each site we interviewed as many cattle ranch administrators or owners (hereafter ranchers) as possible and asked if their livestock had suffered attacks from carnivores within the previous 5 years (2003-2007). We only interviewed ranchers who had been working on the ranch during the 5 years encompassed by this study. Interviews were conducted, by JRS and a field assistant, during June-August 2007. Ranches were then classified as either reporting attacks or not.

\section{Patterns of predation}

We asked a suite of questions about each reported incident. Only first-hand reports of attacks were accepted and the reliability of each incident was assessed based on

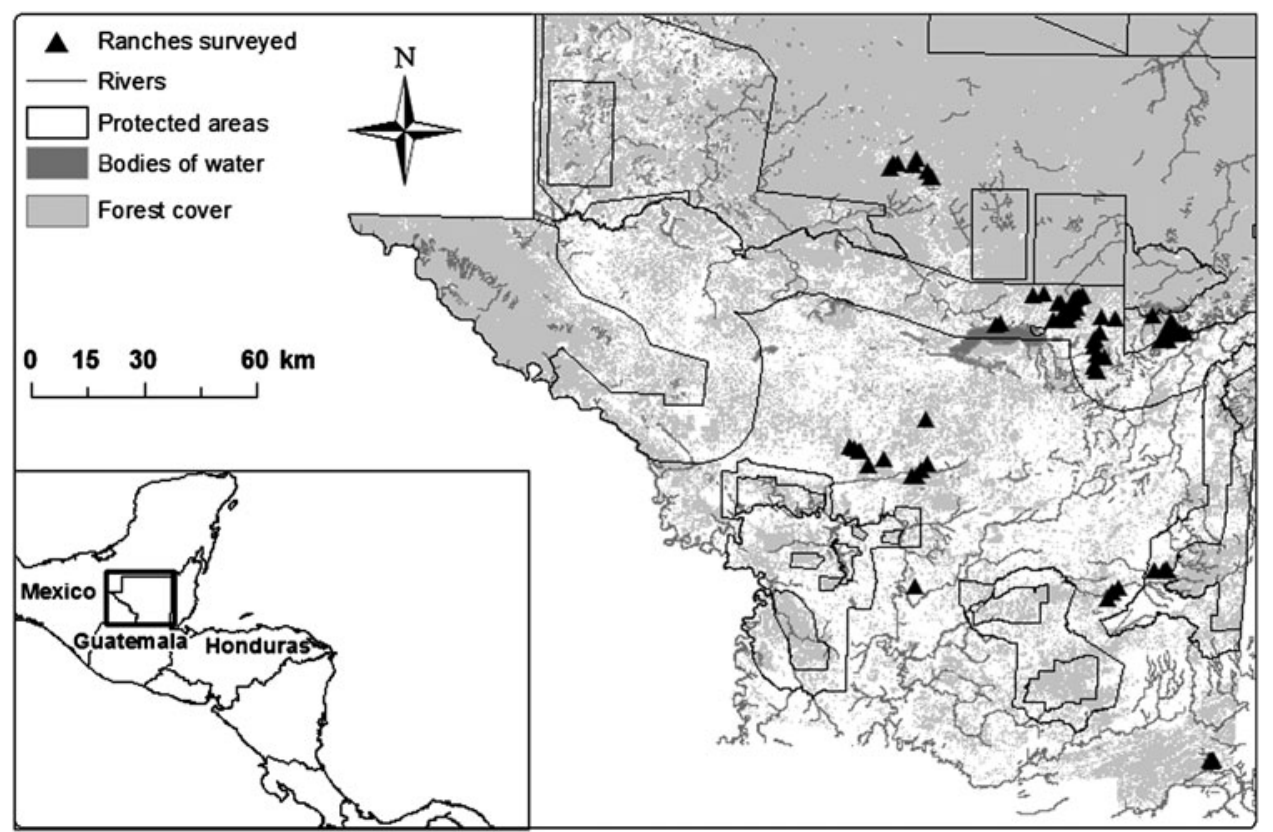

FIG. 1 The study area, showing the ranches surveyed in the Petén District, Guatemala, in 2007. The inset indicates the location of the main figure in Mesoamerica. 
TABLE 1 Questions asked of cattle ranchers in the Petén District, Guatemala (Fig. 1), in 2007.

1. What size is your ranch?

2. How many head of cattle do you keep in this ranch?

3. Do you keep females \& calves in maternity pastures at a distance from forest cover?

4. Do you keep adult males in the same pastures as females \& calves?

5. Do you regulate the calving season?

6. Have you suffered any livestock attacks by carnivores in the last 5 years?

7. How did you know it was a carnivore attack?

8. What animal do you believe was responsible for the attack? Why?

9. Approximate date \& time of the attack?

10. Type of livestock or animal attacked (cattle, goat, chicken, pig, horse, other)?

11. Approximate age of livestock attacked?

12. Approximate weight of livestock attacked?

13. Approximate value of livestock attacked?

14. Sex of livestock attacked?

expert-based indications of an attack (i.e. signs of struggle on the ground and surroundings, presence of bite or scratch marks on carcass, body parts consumed, carnivore tracks near attack site or carcass, carcass dragged and hidden or covered under a leaf pile; Hoogesteijn et al., 1993, 2002; Palmeira et al., 2008). We discarded second-hand reports or reports with insufficient or no evidence of a carnivore attack. For most analyses we pooled attacks regardless of the carnivore thought to be responsible as the majority of interviewees had no prior experience in distinguishing attacks of the carnivore species inhabiting the area.

For each reported attack we recorded the carnivore believed responsible, type of livestock or animal attacked (cattle, goat, horse, pig or dog), and time of day and date of incident. Time was categorized as night (18.00-05.59), morning (06.00-11.59), or afternoon (12.00-17.59) because in many cases the hour was not exactly known. $\chi^{2}$ goodness of fit tests were used to determine whether species of attacker (jaguar, puma or coyote Canis latrans), type of livestock attacked, and time of day were equal for all categories; Fisher's exact tests were used when frequencies of responses were small (Zar, 1999). We performed Spearman rank correlations $\left(r_{s}\right)$ to examine associations between frequency of attacks per month and mean monthly rainfall for all attacks reported, and for attacks on cattle separately because the latter is the most abundant type of livestock in the area. Statistical significance was $\mathrm{P} \leq 0.05$ for all analyses. We recorded sex and weight of cattle attacked. Cattle weights were categorized into nine classes $(11.4-450 \mathrm{~kg})$. $\chi^{2}$ goodness of fit tests were used to determine whether attacks occurred on both sexes equally. Spearman rank correlations were used to examine the relationship between number of attacks and weight of animals attacked. A total and mean annual monetary loss during the study period was obtained for cattle by asking ranchers to estimate the cost of animals attacked and converting estimates to USD at an exchange rate of GTQ 7.60 = USD 1.00. We estimated percentage of cattle lost to predators based on the total number of cattle reported by each rancher.

\section{Livestock husbandry practices}

We asked if ranchers applied livestock husbandry practices that previous researchers (Hoogesteijn et al., 1993; Hoogesteijn, 2001; Polisar et al., 2003; Hoogesteijn \& Hoogesteijn, 2010) have recommended to reduce the probability of predation on livestock by large felids (Table 1). More specifically, we asked if ranchers kept calves and females in maternity pastures at a distance from forest cover, if they kept older, more experienced males with calves and females, and if they regulated calving season to concentrate calves and provide better protection for them. This information was analysed qualitatively because of homogeneous practices among the ranches.

\section{Predictors of predation}

For each ranch surveyed we recorded the geographical coordinates, with a global positioning system (GPS), of the main ranch house. This was done because in some instances ranchers did not allow us access to their pastures. The layout of most ranches surveyed is similar, with the main ranch house located at the entrance to the ranch and the pastures directly behind the main house (J. Soto, pers. obs.). We used a geographical information system to quantify landscape structure in and around each ranch using raster and vector shape files previously classified by the National Council of Protected Areas (CONAP), Guatemala. Roads and land cover classes were based on a 2003 Landsat image of the area, and GPS way-points for roads recorded by CONAP personnel. Although 15 land cover classes were defined in the image we used only the broad-leaf forest class in our analyses as this was the predominant and most extensive type of natural forest. Thornton (2010) assessed the accuracy of the same Landsat image of the area by ground-truthing and by comparisons with aerial photographs, obtaining an accuracy of $91 \%$ for forest classes. Rivers and lakes were digitized from 1:50,000 cartographic maps obtained from the National Institute of Geography, Guatemala (IGN). Location of human settlements was based on GPS way-points collected by CONAP personnel. We measured forest cover and the Euclidean distance from the ranch to forest cover, human settlements, rivers, bodies of water (i.e. lakes, lagoons) and roads using ArcGIS v. 9.o (ESRI, Redlands, California). To calculate forest cover we created a $5-\mathrm{km}$ buffer around each ranch point and estimated forest cover in each buffer.

We recorded two ranch characteristics (Table 2) and six variables related to landscape structure near ranches. 
Inter-correlation amongst these variables was evaluated with a Pearson's correlation test $(r>0.5)$, and we excluded two potential explanatory variables (distance to roads and rivers) that were highly correlated $(r=0.83)$.

We compared ranches with and without attacks using a logistic regression analysis of a priori models based on various combinations of explanatory and predictor variables, and used Akaike's Information Criterion (AIC; Burnham \& Anderson, 2002) to compare models and identify the model or models that received the most support for explaining occurrence of predation by carnivores. The various combinations of models that formed the basis were: ranch characteristics (size of ranch and number of cattle) and landscape variables. The landscape variables were subdivided into models containing only variables related to forest cover, water sources and human influence to test for the effect of these variables on the occurrence of predation. We compared AIC values, corrected for small sample size $\left(\mathrm{AIC}_{\mathrm{C}}\right), \mathrm{AIC}_{\mathrm{C}}$ differences $\left(\triangle \mathrm{AIC}_{\mathrm{C}}\right)$, and the Akaike weights $\left(\mathrm{AIC}_{\mathrm{C}} w t\right)$ for models with different combinations of predictor variables based on these categories (Burnham \& Anderson, 2002). We used a Hosmer-Lemeshow goodness of fit test to examine the fit $(\alpha \leq 0.05)$ for each model proposed (Hosmer \& Lemeshow, 2000). All statistical analyses were performed using SAS v. 9.1 (SAS Institute, 2003).

TABLE 2 Variables used to summarize characteristics of ranches and their surrounding landscape in the Petén District, Guatemala, measured in 2007.

\begin{tabular}{|c|c|c|}
\hline Variable & Unit & Source \\
\hline \multicolumn{3}{|l|}{ Ranch characteristics } \\
\hline Size of ranch & ha & Questionnaire \\
\hline No. of cattle per ranch & & Questionnaire \\
\hline \multicolumn{3}{|l|}{ Landscape characteristics } \\
\hline \multicolumn{3}{|l|}{ Forest cover } \\
\hline $\begin{array}{l}\text { Amount of forest cover } \\
\text { around ranch }\end{array}$ & $\mathrm{m}^{2}$ & $\begin{array}{l}2003 \text { Landsat } \\
\text { image (CONAP) }\end{array}$ \\
\hline Distance to forest cover & $\mathrm{m}$ & $\begin{array}{l}2003 \text { Landsat } \\
\text { image (CONAP) }\end{array}$ \\
\hline \multicolumn{3}{|l|}{ Water sources } \\
\hline Distance to rivers ${ }^{\star}$ & $\mathrm{m}$ & $\begin{array}{l}1: 50,000 \text { cartographic } \\
\text { maps (IGN) }\end{array}$ \\
\hline $\begin{array}{l}\text { Distance to other water } \\
\text { bodies (lakes, } \\
\text { lagoons) }\end{array}$ & $\mathrm{m}$ & $\begin{array}{l}1: 50,000 \text { cartographic } \\
\text { maps (IGN) }\end{array}$ \\
\hline \multicolumn{3}{|l|}{ Human influence } \\
\hline $\begin{array}{l}\text { Distance to human } \\
\text { settlements }\end{array}$ & $\mathrm{m}$ & $\begin{array}{l}\text { GPS way-points } \\
\text { (CONAP) }\end{array}$ \\
\hline Distance to roads ${ }^{*}$ & $\mathrm{~m}$ & $\begin{array}{l}2003 \text { Landsat image \& } \\
\text { GPS way-points } \\
\text { (CONAP) }\end{array}$ \\
\hline
\end{tabular}

${ }^{*}$ Discarded because of high inter-correlation (see text).

\section{Results}

We surveyed 83 ranches, of which 32 provided reliable reports of 104 incidents of predation on livestock. The mean size of surveyed ranches was 175.9 \pm SE 41.6 ha (range 11.2-2,688.0 ha, $\mathrm{n}=70$ ), with a high percentage of small ranches (11.2-500.0 ha, $\mathrm{n}=66,94 \%)$ and few medium-sized $(>500.0-1,000.0$ ha, $n=2,3 \%)$ or large $(>1,000.0$ ha, $\mathrm{n}=2,3 \%)$ ranches. The mean number of cattle per ranch was $120.5 \pm$ SE 17.6 (range $5-750, n=69$ ). Most ranches had 1-99 cattle ( $\mathrm{n}=44,64 \%)$; fewer ranches had 100-199 cattle $(\mathrm{n}=16,23 \%), 200$ to 299 -cattle $(\mathrm{n}=3,4 \%)$, or $\geq 300$ cattle $(\mathrm{n}=6,9 \%)$.

The jaguar was the carnivore most accused of attacks on livestock ( $78.9 \%$ of all attacks, $\mathrm{P}<0.001, \mathrm{n}=104$; Table 3 ) and the puma and coyote were accused of 15.4 and $5.8 \%$ of attacks, respectively. Cattle was the type of livestock most attacked, followed by goats (Table 3). Most attacks occurred at night $(\mathrm{P}<0.001, \mathrm{n}=100)$ and during the rainy season $(\mathrm{P}<0.001, \mathrm{n}=99)$. Attacks were associated with monthly rainfall $\left(r_{s}=0.590 ; \mathrm{P}=0.044, \mathrm{n}=100\right.$; Fig. 2$)$. Most attacks on cattle occurred at night $(\mathrm{P}<0.001, \mathrm{n}=55)$ and during the rainy season $(\mathrm{P}<0.001, \mathrm{n}=57)$. Attacks on cattle were not associated with mean monthly rainfall $\left(r_{s}=0.527, \mathrm{P}=0.079\right.$, $\mathrm{n}=55)$ but inversely related to the weight class of cattle predated $\left(r_{s}=-0.815, \mathrm{P}=0.007\right.$; mean $=135.1 \pm \mathrm{SE} 11.5 \mathrm{~kg}$, range $11.4-431.8 \mathrm{~kg}, \mathrm{n}=56$ ). Most attacks were on cattle between 11.4 and $227.3 \mathrm{~kg}$, with a high number of attacks occurring on cattle of $11.4-50.0 \mathrm{~kg}$ and $151.0-200.0 \mathrm{~kg}$ (28.6 and $23.2 \%$, respectively; Table 4 ). Male cattle were attacked more than females $(P=0.001, n=44)$.

The total economic loss from predation on cattle by large carnivores during the study period was estimated to be USD 14,736 and mean annual loss was USD 2,947 \pm SE 1,491 . Of all cattle reported in the study, $0.7 \%$ were lost to carnivores. Most ranchers $(90 \%, \mathrm{n}=71)$ kept calves and females with adult males but few ranchers kept calves in maternity pastures away from forest cover $(11 \%, \mathrm{n}=72)$ or regulated calving season $(27 \%, \mathrm{n}=70)$. The only supported model for explaining occurrence of predation incidents in the study area consisted of all landscape variables (model fit $\mathrm{P}=0.226$; Table 5); other models were poor, with low Akaike weights $\left(w_{i} \leq 0.01\right)$.

TABLE 3 Number of predation incidents on livestock reported by ranchers to have been carried out by jaguar Panthera onca, Puma Puma concolor and coyote Canis latrans in the Petén District, Guatemala, during 2003-2007.

\begin{tabular}{lcclc}
\hline Livestock & Jaguar & Puma & Coyote & Total \\
\hline Cattle & 56 & 3 & 1 & 60 \\
Goats & 12 & 12 & 5 & 29 \\
Horses & 7 & 1 & 0 & 8 \\
Dogs & 7 & 0 & 0 & 7 \\
Total & 82 & 16 & 6 & 104 \\
\hline
\end{tabular}




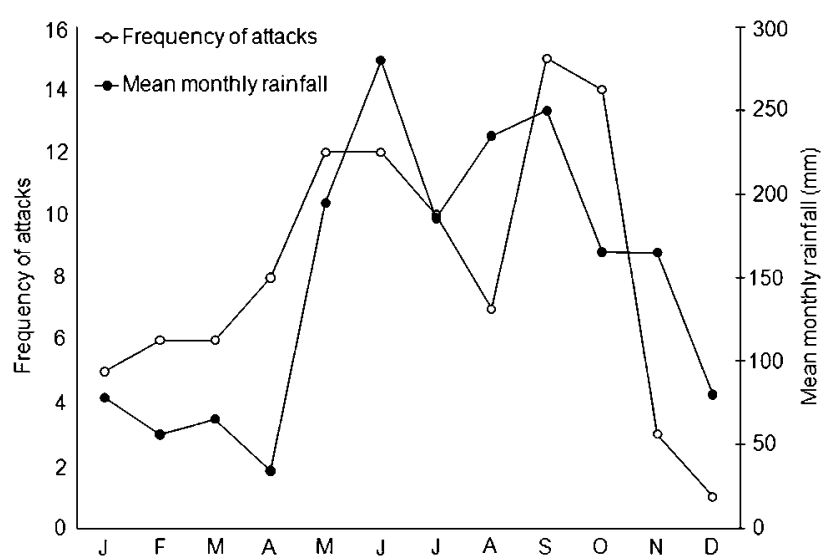

FIG. 2 Total number of monthly predation incidents on livestock by carnivores and mean monthly rainfall per month in Petén District, Guatemala (Fig. 1), for 2003-2007.

\section{Discussion}

Our results could have been influenced by the fact that the sites surveyed were selected from a survey of government and NGO personnel, and complete coverage of the Petén District by these organizations is unlikely. This can be seen in the homogeneous characteristics of the ranches surveyed (i.e. a high percentage of small ranches with a low number of cattle) and the relatively small number of ranches surveyed within the Maya Biosphere Reserve. Consequently, our study should be interpreted with caution as it may only apply to small ranches and to the sites surveyed. Nevertheless, small ranches with low numbers of cattle are predominant throughout Petén District.

Cattle loss to carnivores in the area we surveyed constitutes a minor percentage of all cattle reported $(0.7 \%)$. This is comparable to estimates in other areas: $0.56 \%$ of the total livestock on a ranch were predated by jaguars and pumas in the Pantanal, western Brazil (Azevedo \& Murray, 2007), 0.3\% in the Iguaçu National Park area in southern Brazil (Azevedo, 2008), and 0.4\% in central-western Brazil (Palmeira et al., 2008). Previous

TABLE 4 Number (\%) of predation incidents on cattle, by weight classes of individuals attacked, in the Petén District, Guatemala, 2003-2007.

\begin{tabular}{lc}
\hline Cattle weight class $(\mathrm{kg})$ & No. of attacks $(\%)$ \\
\hline $11.4-50.0$ & $16(28.57)$ \\
$51.0-100.0$ & $4(7.14)$ \\
$101.0-150.0$ & $10(17.86)$ \\
$151.0-200.0$ & $13(23.21)$ \\
$201.0-250.0$ & $10(17.86)$ \\
$251.0-300.0$ & $2(3.57)$ \\
$301.0-350.0$ & 0 \\
$351.0-400.0$ & 0 \\
$401.0-450.0$ & $1(1.79)$ \\
Total & 56 \\
\hline
\end{tabular}

studies have shown that livestock mortality from predators may be negligible compared to losses from other causes (Hoogesteijn et al., 1993; Mazolli et al., 2002; Polisar et al., 2003; Michalski et al,. 2006; Azevedo \& Murray, 2007; Azevedo, 2008; Palmeira et al., 2008). In our study area a high percentage of ranchers identified disease (black leg, a highly infectious bacterial disease that affects sheep and cattle) to be a primary cause of livestock mortality, followed by poisonous snake bites, and few ranchers recognized predation on livestock as a major source of mortality (J.R. Soto-Shoender, unpubl. data). Nevertheless, when cattle ranching is the primary economic activity and a rancher owns a small number of cattle or other livestock, any loss may be considered significant (Saenz \& Carrillo, 2002; Rosas-Rosas et al., 2008, 2010) and result in retaliatory measures and cause a negative attitude towards carnivores. Therefore, even though the overall effect of carnivores on livestock appears minimal, it is a problem that can lead to negative impacts on both local people and carnivore populations in areas with small cattle ranches such as the Petén District.

The jaguar was accused of the highest percentage of the attacks in our study. However, this should be interpreted with caution, as the culprit of attack was not systematically identified in most cases and local knowledge and perception of carnivore species may have influenced the findings. Conforti \& Azevedo (2003) also reported a tendency for local people to blame jaguars for attacks on livestock. This may be attributed to insufficient local knowledge of pumas (Conforti \& Azevedo, 2003) and coyotes. The occurrence of the coyote in this area is relatively recent (J.R. SotoShoender, pers. obs.) and local people may still be learning to identify this predator. Attacks could also be the act of feral or domestic dogs (Sillero-Zubiri \& Laurenson, 2001). Nevertheless, the high number of attacks blamed on jaguars, despite a lack of supporting evidence, suggests a negative perception of jaguars that could negatively affect this felid.

Our results are consistent with studies in other regions that found higher predation rates on younger age classes of cattle (Hoogesteijn et al., 1993; Polisar et al., 2003; Michalski et al., 2006; Palmeira et al., 2008). Palmeira et al. (2008) and Michalski et al. (2006) found higher predation rates on newborn cattle and cattle up to 8 and 5 months old, respectively, and a small number of attacks on cattle older than 12 months, which is consistent with our observation of only three attacks on cattle over $250.0 \mathrm{~kg}$. In addition, we also detected a higher number of attacks on male than on female calves. Palmeira et al. (2008) also found this pattern, suggesting it was the result of male calves being more independent of their mothers.

Most attacks occurred at night and during the rainy season. Researchers have speculated that attacks may be higher during wetter months because ranchers are less 
TABLE 5 Comparison of candidate models predicting predation on livestock by carnivores in the Petén District, Guatemala, 2003-2007.

\begin{tabular}{|c|c|c|c|c|c|}
\hline Model type & $\mathrm{K}^{1}$ & $\mathrm{AIC}_{\mathrm{C}}^{2}$ & $\Delta \mathrm{AIC}_{\mathrm{C}}{ }^{3}$ & $\mathrm{AIC}_{\mathrm{C}} w t^{4}$ & Variables in model $^{5}$ \\
\hline Landscape & 5 & 43.53 & 0.00 & 0.99 & $\begin{array}{l}\text { Distance to forest cover }+ \text { Amount of forest } \\
\text { cover around ranch }+ \text { Distance to other } \\
\text { water bodies }+ \text { Distance to human } \\
\text { settlements }\end{array}$ \\
\hline Global (containing all variables) & 7 & 44.91 & 1.37 & $<0.01$ & $\begin{array}{l}\text { Distance to forest cover }+ \text { Amount of forest } \\
\text { cover around ranch }+ \text { Distance to other } \\
\text { bodies of water }+ \text { Distance to human } \\
\text { settlements }+ \text { Ranch size }+ \text { No. of cattle per } \\
\text { ranch }\end{array}$ \\
\hline Influence of forest cover & 3 & 47.74 & 4.21 & $<0.01$ & $\begin{array}{l}\text { Distance to forest cover }+ \text { Amount of forest } \\
\text { cover around ranch }\end{array}$ \\
\hline Ranch characteristics & 3 & 57.06 & 13.53 & $<0.01$ & Ranch size + No. of cattle per ranch \\
\hline Influence of water sources & 2 & 63.43 & 19.89 & $<0.01$ & Distance to other water bodies \\
\hline Human influence & 2 & 62.86 & 19.32 & $<0.01$ & Distance to human settlements \\
\hline
\end{tabular}

${ }^{1} \mathrm{~K}$, number of parameters in model (includes an intercept term, $\beta_{\mathrm{o}}$ )

${ }^{2} \mathrm{AIC}_{\mathrm{C}}$, AIC estimate corrected for small sample size

${ }^{3} \Delta \mathrm{AIC}_{\mathrm{C}}$, difference of the $\mathrm{AIC}_{\mathrm{C}}$ values between the most supported model and the given model

${ }^{4} \mathrm{AIC}_{\mathrm{C}} w t$, Akaike weight for each model

${ }^{5}$ Table 2

active afield during these conditions (Mazolli et al., 2002), limiting the amount of time people are near their cattle, which may otherwise deter predation. Furthermore, carnivores may be more difficult to detect, by both people and livestock, during periods of high rainfall and jaguars and pumas have been found to be more active during wetter months when temperatures are lower and prey are more dispersed and not concentrated around permanent water sources (Scognamillo et al., 2003). An increase in predation during wetter months has been reported in other regions (Mazolli et al., 2002; Saenz \& Carrillo, 2002). Palmeira et al. (2008) also found a higher predation rate during the wetter months but related this to the majority of calf births occurring during this period. Michalski et al. (2006) found the opposite, with an increase in attacks during drier months, primarily related to the timing of calving. Other studies have also found a correlation between predation and peaks in calving (Polisar et al., 2003; Scognamillo et al., 2003). Most ranchers in our study area did not regulate calving seasons; nevertheless, as the ranchers questioned do not keep detailed records of their operations we cannot speculate whether the strong seasonal pattern of predation incidents is related to calving season or seasonal differences in carnivore and prey ecology.

Conflicts with jaguars, pumas and coyotes occur only in Mexico and Central America where the ranges of these three carnivores overlap, particularly in areas with high rates of deforestation (Hidalgo-Mihart et al., 2004) such as the Petén District. If the trend of increasing deforestation in the area continues (Hayes et al., 2002), we would expect an increase in coyote populations and a concomitant increase in human-coyote conflicts (Cuaron, 2000). Consequently, higher rates of conflicts with coyotes may exacerbate conservation problems for threatened species such as the jaguar as local people tend to blame jaguars for predation on livestock. Coyotes are intense livestock predators (Knowlton et al., 1999; Sillero-Zubiri \& Laurenson, 2001) and the control and prevention of predation by coyotes requires species-specific measures (Knowlton et al., 1999). These measures are only now being included in recommendations to mitigate human-carnivore conflicts in the neotropics (J.R. Soto-Shoender, pers. obs.).

Livestock husbandry practices were homogeneous throughout our study area, regardless of ranch size or location. In this region livestock husbandry practices have been described as rudimentary (Saenz \& Carrillo, 2002) and, as shown by our study, most ranches do not apply some of the practices recommended to prevent predation on livestock (i.e. keeping calves and females in secure pens at night), despite reports of predation. Although ranchers did keep females and calves with older males most ranches are cattle-breeding operations and keep a low percentage of males in their stock (J.R. Soto-Shoender, unpubl. data), and thus the practice is not an effective preventive measure.

Ranchers may not modify their practices to prevent predation on livestock because they do not have the knowledge or capacity to do so or because of a negative attitude towards carnivores and conservation (J.R. Soto-Shoender, pers. obs.). In other areas people were reluctant to modify husbandry practices to prevent predation on livestock (Oli et al., 1994; Weber \& Rabinowitz, 1996; Mazolli et al., 2002). Additionally, predation on livestock in our study area is not a regularly occurring problem and may not therefore warrant the investment required to modify traditional practices. Consequently, eliminating the animal believed responsible for the attacks may appear to be a more effective and economic measure to the rancher (J.R. Soto-Shoender, pers. obs.). 
Our hypothesis that ranch characteristics and landscape variables around ranches influenced the occurrence of predation on livestock by carnivores was only partially supported. Our analysis indicated that landscape variables were the only important predictors of predation and we did not detect an influence of ranch characteristics. This finding is consistent with other studies (Michalski et al., 2006; Azevedo \& Murray, 2007; Palmeira et al., 2008) that have identified landscape variables such as proximity to forests and water sources and amount of forest area surrounding ranches as major predictors of conflicts with carnivores. These characteristics may be important predictors because they also describe prime carnivore habitat and sites where there is a high probability of carnivore presence (Rabinowitz, 2005). Consequently, any ranch in the study area near adequate forest cover and water sources and at a considerable distance from human settlements is at risk of suffering predation of its livestock by carnivores unless husbandry practices are modified.

We recommend implementing outreach and education programmes to promote the application of conflict mitigation efforts on ranches near forest cover and water sources. Protection for livestock on these ranches should concentrate on calves, especially during the wetter months. This can be done through regulating birth seasons when possible and maintaining maternity pastures, and building secure corrals in which to pen animals at night at a distance from forest cover and near human presence (Mazolli et al., 2002; Palmeira et al., 2008; Hoogesteijn \& Hoogesteijn, 2010). A further recommendation is to train local government and NGO personnel in predator identification and conflict mitigation techniques. Research on ranches within the Maya Biosphere Reserve should be a priority, as predation on livestock, and consequently jaguar and puma mortality, may be more severe in these sites. Finally, implementation of monitoring of livestock mortality would help determine the scale of the problem and the extent to which each carnivore species contributes to predation on livestock.

These recommendations are currently being implemented in the study area by a consortium of government organizations (Wildlife Service Department and Ministry of Agriculture and Cattle Ranching) and local conservation NGOs. The ranchers also receive free veterinary services (e.g. livestock vaccinations and nutritional supplements) and advice. This human-carnivore conflict mitigation and monitoring programme has now been running for 2 years and there has been a positive response from local ranchers.

\section{Acknowledgements}

This study was authorized by the Institutional Review Board (IRB) of the University of Florida (UFIRB study number 2007-U-372). We are grateful for the financial support provided by the United States Department of State (award number S-LMAQM-07-CA-312), University of Florida, Chester Zoo, and the Jaguar Conservation Program of the Wildlife Conservation Society. We thank the Fulbright Program, Organization of American States, and the Center for Latin American Studies Program of the University of Florida for a graduate scholarship to JS, the Wildlife Conservation Society Guatemala for logistical support, Guillermo Lopez, Wilfredo Raxon, Melvin Merida, Tomas Dubon, Jose Lopez and Ambrocio Marin for assistance in the field, all government and NGO personnel and the cattle ranchers who participated in this study, and the Evaluation and Monitoring Center of the National Council of Protected Areas, especially Victor Hugo Ramos, in Guatemala for providing the ArcGIS layers used in this study.

\section{References}

Azevedo, F.C. (2008) Food habits and livestock predation of sympatric jaguars and pumas in the Iguacu National Park Area, South Brazil. Biotropica, 40, 494-500.

Azevedo, F.C. \& Murray, D.L. (2007) Evaluation of potential factors predisposing livestock to predation by jaguars. Journal of Wildlife Management, 71, 2379-2386.

Burnham, K.P. \& Anderson, D.R. (2002) Model Selection and Multimodel Inference: A Practical Information-Theoretic Approach. 2nd edition. Springer-Verlag, New York, USA.

Conforti, V.A. \& Azevedo, F. (2003) Local perceptions of jaguars (Panthera onca) and pumas (Puma concolor) in the Iguaçu National Park area, south Brazil. Biological Conservation, 111, 215-221.

Crawshaw, P. (2004) Depredation of domestic animals by large cats in Brazil. Human Dimensions of Wildlife, 9, 329-330.

CUARON, A.D. (2000) Effects of land-cover changes on mammals in a neotropical region: a modelling approach. Conservation Biology, 14, 1676-1692.

Graham, K., Beckerman, A.P. \& Thirgood, S. (2004) Humanpredator-prey conflicts: ecological correlates, prey losses and patterns of management. Biological Conservation, 122, 159-171.

Grunberg, W. (2000) Modelling deforestation risk in the Maya Biosphere Reserve, Guatemala. MSc thesis, University of Arizona, USA.

Hayes, D.J., Sader, S.A. \& Schwartz, N.M. (2002) Analyzing a forest conversion history database to explore the spatial and temporal characteristics of land cover change in Guatemala's Maya Biosphere Reserve. Landscape Ecology, 17, 299-314.

Hidalgo-Mihart, M.G., Cantu-Salazar, L., GonZalezRomero, A. \& Lopez-Gonzalez, C.A. (2004) Historical and present distribution of coyote (Canis latrans) in Mexico and Central America. Journal of Biogeography, 31, 2025-2038.

Hoogesteijn, R. (2001) Manual on the Problem of Depredation Caused by Jaguars and Pumas on Cattle Ranches. Unpublished Report to the Wildlife Conservation Society.

Hoogesteijn, R., Boede, E.O. \& Mondolfi, E. (2002) Observaciones de la depredación de bovinos por jaguares en Venezuela y los programas gubernamentales de control. In El jaguar en el nuevo milenio: una evaluación de su estado, detección de prioridades y recomendaciones para la conservación de los jaguares en América (eds R.A. Medellín, C.L.B. Chetkiewicz, A. Rabinowitz, K.H. Redford, J.G. Robinson, E.W. Sanderson \& A.B. Taber), 
pp. 183-197. Universidad Nacional Autónoma de México/Wildlife Conservation Society, México.

Hoogesteijn, R. \& Hoogesteijn, A. (2010) Conserving felids in humanized landscapes: strategies for reducing conflicts between jaguars and cattle. Wild Felid Monitor, 3, 10-13

Hoogesteijn, R., Hoogesteijn, A. \& Mondolfi, E. (1993) Jaguar predation and conservation: cattle mortality caused by felines on three ranches in the Venezuelan llanos. In Mammals as Predators (eds N. Dunstone \& M.L. Gorman), pp. 391-407. Zoological Society, London, UK

Hosmer, Jr, D.W. \& Lemeshow, S. (2000) Applied Logistic Regression. 2nd edition. John Wiley \& Sons, New York, USA.

Inskip, C. \& Zimmermann, A. (2009) Human-felid conflict: a review of patterns and priorities worldwide. Oryx, 43, 18-34.

Instituto Nacional DE Estadística (2003) Technical Report. Censo Agropecuario Nacional, Guatemala.

Knowlton, F.F., Gese, E.M. \& Jaeger, M.M. (1999) Coyote depredation control: an interface between biology and management. Journal of Range Management, 52, 398-412.

Mazolli, M., Graipel, M.E. \& Dunstone, N. (2002) Mountain lion depredation in southern Brazil. Biological Conservation, 105, 43-51.

MCNAB, R. \& Polisar, J. (2002) Una metodología participativa para una estimación rápida de la distribución del Jaguar (Panthera onca) en Guatemala. In El jaguar en el nuevo milenio: una evaluación de su estado, detección de prioridades y recomendaciones para la conservación de los jaguares en América (eds R.A. Medellín, C.L.B. Chetkiewicz, A. Rabinowitz, K.H. Redford, J.G. Robinson, E.W. Sanderson \& A.B. Taber), pp. 73-89. Universidad Nacional Autónoma de México/Wildlife Conservation Society, México.

Michalski, F., Boulhosa, R.L.P., Faria, A. \& Peres, C.A. (2006) Human-wildlife conflicts in a fragmented Amazonian forest landscape: determinants of large felid depredation on livestock. Animal Conservation, 9, 179-188.

Novack, A.J., Main, M.B., Sunquist, M.E. \& Labisky, R.F. (2005) Foraging ecology of jaguar (Panthera onca) and puma (Puma concolor) in hunted and non-hunted sites within the Maya Biosphere Reserve, Guatemala. Journal of Zoology, 267, 167-178.

Ogada, M.O., Woodroffe, R., OGuge, N.O. \& Frank, L.G. (2003) Limiting depredation by African carnivores: the role of livestock husbandry. Conservation Biology, 17, 1521-1530.

Oli, M.K., Taylor, I.R. \& Rogers, M.E. (1994) Snow leopard (Panthera uncia) predation of livestock: an assessment of local perceptions in the Annapurna Conservation Area, Nepal. Biological Conservation, 68, 63-68.

Palmeira, F.B.L., Crawshaw, P.G., Haddad, C.M., Ferraz, K.M. \& VERDADE, L.M. (2008) Cattle depredation by puma (Puma concolor) and jaguar (Panthera onca) in central-western Brazil. Biological Conservation, 141, 118-125.

Polisar, J., Maxit, I., Scognamillo, D., Farell, L., Sunquist, M.E. \& EISENBERG, J.F. (2003) Jaguars, pumas, their prey base, and cattle ranching: ecological interpretations of a management problem. Biological Conservation, 109, 297-310.

Quigley, H.B. \& Crawshaw, JR, P.G. (1992) A conservation plan for the jaguar Panthera onca in the Pantanal region of Brazil. Biological Conservation, 61, 149-157.

RABinowitz, A. (1986) Jaguar predation on domestic livestock in Belize. Wildlife Society Bulletin, 14, 170-174.

Ra Binowitz, A. (2005) Jaguars and livestock: living with the world's third largest cat. In People and Wildlife, Conflict or Co-existence? (eds R. Woodroffe, S. Thirgood \& A. Rabinowitz), pp. 278-285. Cambridge University Press, Cambridge, UK.

Rosas-Rosas, O., Bender, L.C. \& Valdez, R. (2008) Jaguar and puma predation on cattle calves in Northeastern Sonora, Mexico. Rangeland Ecology \& Management, 61, 554-560.
Rosas-Rosas, O., Bender, L.C. \& Valdez, R. (2010) Habitat correlates of jaguar kill-sites of cattle in northeastern Sonora, Mexico. Human-Wildlife Interactions, 4, 103-111.

SAenz, J. \& CARrillo, E. (2002) Jaguares depredadores de ganado en Costa Rica: ¿un problema sin solución? In El jaguar en el nuevo milenio: una evaluación de su estado, detección de prioridades y recomendaciones para la conservación de los jaguares en América (eds R.A. Medellín, C.L.B. Chetkiewicz, A. Rabinowitz, K.H. Redford, J.G. Robinson, E.W. Sanderson \& A.B. Taber), pp. 127-137. Universidad Nacional Autónoma de México/Wildlife Conservation Society, México.

Sanderson, E.W., Redford, K.H., Chetriewicz, C.B., Medellin, R.A., Rabinowitz, A.R., Robinson, J.G. \& TABER, A.B. (2002) Planning to save a species: the jaguar as a model. Conservation Biology, 16, 58-72.

SAS Institute (2003) SAS for Windows v. 9.1. SAS Institute, Inc., Cary, USA.

Scognamillo, D., Maxit, I.E., Sunquist, M. \& Polisar, J. (2003) Coexistence of jaguar (Panthera onca) and puma (Puma concolor) in a mosaic landscape in the Venezuelan llanos. Journal of Zoology, 259, 269-279.

Sillero-Zubiri, C. \& Laurenson, M.K. (2001) Interactions between carnivores and local communities: conflict or co-existence? In Carnivore Conservation, Conservation Biology Series 5 (eds J.L. Gittleman, M.S. Funk, D. Macdonald \& R.K. Wayne), pp. 282-312. Cambridge University Press, Cambridge, UK.

Sunquist, M. (2002) Historia de la investigación sobre el jaguar en el continente americano. In El jaguar en el nuevo milenio: una evaluación de su estado, detección de prioridades y recomendaciones para la conservación de los jaguares en América (eds R.A. Medellín, C.L.B. Chetkiewicz, A. Rabinowitz, K.H. Redford, J.G. Robinson, E.W. Sanderson \& A.B. Taber), pp. 535-549. Universidad Nacional Autónoma de México/Wildlife Conservation Society, México.

ThORNTON, D.H. (2010) The influence of species traits and landscape attributes on the response of mid- and large-sized neotropical mammals to forest fragmentation. $\mathrm{PhD}$ thesis, University of Florida, Gainesville, USA.

Treves, A., Wallace, R.B., Naughton-Treves, L. \& Morales, A. (2006) Co-managing human-wildlife conflicts: a review. Human Dimensions of Wildlife, 11, 383-396.

Weber, M. \& Rabinowitz, A.R. (1996) Global perspectives on large carnivore conservation. Conservation Biology, 10, 1047-1054.

Woodroffe, R. \& Ginsberg, J.R. (1998) Edge effects and the extinction of populations inside protected areas. Science, 280, 2126-2128.

ZAR, J.H. (1999) Biostatistical Analysis. 4th edition. Prentice Hall, Upper Saddle River, USA.

Zimmermann, A., Walpole, M.J. \& Leader-Williams, N. (2005) Cattle ranchers' attitudes to conflicts with jaguar (Panthera onca) in the Pantanal of Brazil. Oryx, 39, 406-412.

\section{Biographical sketches}

Jose Soto-Shoender has worked in wildlife research and conservation programmes in the tropical lowlands of Guatemala for 9 years and is interested in understanding and mitigating the impacts of human activities on neotropical wildlife, especially carnivores and their prey. William M. Giuliano is a wildlife conservationist who has worked on conservation education and wildlife management issues in Central and North America for more than 15 years, with a particular interest in developing methods to integrate wildlife conservation with other land uses. 